\title{
Women in Local Government: The Pakistan Experience
}

\author{
Saba Gul Khattak*
}

\begin{abstract}
This article looks at women's representation in local government in Pakistan, focusing particularly on the introduction of a quota setting 33 per cent of the seats for women brought in under General Musharraf's Devolution of Power Plan in 2000. The article suggests that establishing a direct correlation between a woman's quota and regime type is problematic. It demonstrates a complex pattern of interaction on the issue by both the military and civilian regimes in Pakistan. Policies which have been brought in, informed both by political pragmatism and ideological continuity, have been wide ranging and almost contradictory in nature. The article also highlights the importance of the roles of NGOs and women activists in providing capacity building and support for mobilising women both as candidates and as voters. It shows that women's struggles at grassroots can bring achievements even in spaces where patriarchal norms rule, but these pathways to political empowerment are uneven and unpredictable.
\end{abstract}

\section{Introduction}

This article looks at women's presence in local government (LG) in Pakistan with a particular focus on the period of the Musharraf regime's 'Devolution of Power Plan' (2000). ${ }^{1}$ In 2000, one of the most significant forms of affirmative action was introduced embodied in a quota setting 33 per cent of the seats for women in local government. While an important achievement for advancing women's representation in political office, this article cautions against interpreting the quota or its implementation as a sign of a more democratic government. I argue that the quota for women was supported by a military regime, while some other civilian regimes were reluctant to support it but instead supported wide-sweeping progressive reforms in other spheres. Establishing direct correlations between leadership support for a women's quota and regime type is highly problematic. An examination of the Pakistani governments' engagement with women's quotas suggests crisscross patterns which are often informed by political pragmatism on the one hand and by ideological continuities on the other. The following section gives a brief overview of the political function and weight of local government across different historical phases; this is followed by a more in-depth examination of the different regimes' engagement with the question of quotas, and how they fit (if at all) within the wider social/political and gender policies pursued. The contentious role played by NGOs and the women's movement in mediating with different regimes to secure women's rights is discussed at length, followed by conclusions.

\section{Historical overview}

Local government (LG) is a critical locale for change in Pakistan. It was mentioned in the Muslim League Manifesto even before Pakistan's creation; and has been a part of various constitutions (1962, 1973). Three military dictators instituted LG reform as a means of ensuring control: General Ayub Khan (1958-69), General Zia-ul-Haq (1977-88) and General Pervez Musharraf (1999-2008). But, LG was not in the limelight during the periods of civilian government: the Pakistan Peoples Party (PPP) (Zulfiqar Ali Bhutto) (1972-7); PPP (Benazir Bhutto) (1988-90 and 1993-6); and the Pakistan Muslim League (PML) (Nawaz Sharif) (1990-3 and 1997-9). However, the 1973 constitution, introduced by the PPP government of Zulfiqar Bhutto, which is still operative, includes LG as a non-binding issue in the section entitled, 'Principles of Policy.' The following two articles set out the government's position on LG: 


\begin{tabular}{lll}
\hline \multicolumn{2}{l}{ Table $\mathbf{1}$ Comparative position of women's seats during LG elections 2001 and $\mathbf{2 0 0 5}$} \\
\hline Category of seat & LG election 2000-1 & LG election 2005 \\
\hline Total No. of available seats & 36,066 & 24,463 \\
Nominations filed & 61,411 (1.7/seat) & $57,275(2.3 /$ seat $)$ \\
Percentage & $170 \%$ & $234 \%$ \\
Rejection/withdrawal & 13,566 & 9,853 \\
Percentage & $37 \%$ & $40 \%$ \\
Contesting candidates & $47,845(1.3 /$ seat $)$ & $47,422(1.9 /$ seat $)$ \\
Percentage & $133 \%$ & $194 \%$ \\
Unopposed seats & 9,007 & 4,089 \\
Percentage & $25 \%$ & $16.80 \%$ \\
Vacant seats & 4,077 & 742 \\
Percentage & $11.3 \%$ & $3 \%$ \\
\hline
\end{tabular}

Source National Reconstruction Bureau (2006).

Article 32. The State shall encourage local Government institutions composed of elected representatives of the areas concerned and in such institutions special representations will be given to peasants, workers and women.

Article 37(i). The State shall:

(i) Decentralise the government administration so as to facilitate expeditious disposal of its business to meet the convenience and requirements of the public.

(Government of Pakistan 1973)

These principles of policy remained only on paper until LG was activated under the military rules of General Zia-ul-Haq and General Musharraf. The LG system allows for representation at the local level and addresses basic municipal functions such as water and sanitation, roads and building, agricultural extension services, community development, and basic health and education delivery. This makes the system popular with authoritarian regimes, as it allows people to be involved in local decision-making and grassroots democratic processes while centralised authoritarian rule can continue.

The three-tiered LG system (Union Council at the village/ward level, Tehsil Council at the subdistrict level and District Council) began with General Ayub Khan's basic democracy through 'basic democrats'. LG was then ignored between
1968 and 1977, but revived by General Zia-ul-Haq in 1979 through provincial ordinances. LG elections were held in 1979, 1983 and 1987 on a non-party basis to ensure support and popularity for the military regime. During the following decade-long civilian democratic rule (1988-99) the LG system became an 'on-again, off-again' phenomenon as each government attempted to garner political support by (re)instituting or undoing the LG system. Although LG elections were held across the country in the first tenure of Nawaz Sharif, in his second term, they were only held in Punjab and Balochistan. As women's quotas were left to provincial governments' discretion, they varied widely between 2 and 25 per cent. LG became barely functional. In 2000, the Musharraf government announced its 'Devolution of Power' programme through the promulgation of the Local Government Ordinance (LGO) 2000 at the federal level. It introduced administrative and fiscal change for $\mathrm{LG},{ }^{2}$ as districts could decide their own budget and spend. Under this new ordinance, local government elections were held in 2001 and 2006.

For the first time in Pakistan's history, the LGO of 2000 provided 33 per cent of the seats for women in all three tiers of LG across the four provinces. These seats were directly elected at village level for Union Councils and indirectly elected at district and sub-district levels for District and Tehsil councils (Yazdani 2003). This 
saw the entry of approximately 36,000 women into local government structures and initiated the process of mainstreaming them in the political arena. For the second round of elections, the government reduced the number of seats at the council level but was forced to keep the women's quota at 33 per cent amidst protests from women councillors and NGOs. The overall reduction in seats resulted in fewer women entering the political scene, but by 2005, more women had mobilised and were contesting the general seats indicating a desire to preserve the gains made over the last two zigzag decades.

As can be seen from Table 1, even though seats were reduced for the 2005 election, a greater percentage of women filed nominations and contested it compared with 2001. There were also fewer vacant seats, especially in Balochistan and North-West Frontier Province (NWFP) at the Tehsil and District Council levels and in Punjab and NWFP at the Union Council level, as women realised that there were gains to be made from becoming representatives.

\section{Military and civilian governments, political parties and women's political representation}

Women's political representation has been a contested domain. The demands for women's inclusion in the political sphere date back to the inception of Pakistan and the allocation of 3 per cent of seats to women in assemblies. Although General Ayub Khan championed women's rights, he also tried to prevent Fatima Jinnah from contesting elections against him by questioning women's fundamental ability to rule the country. General Zia also wanted to prevent Benazir Bhutto from assuming political power, but he still provided a small quota for women at the LG and later federal levels.

There have been differences between the federal and provincial government positions on the modalities for implementing women's quotas. This is primarily because local government has been on the 'concurrent list', meaning that it can be under federal government as well as provincial government purview.

While there is no bar on women from participating in the formulation of different policies, there are no specific mechanisms to include their presence in policymaking. After LGO 2000, the reservation of seats for women in the national and provincial assemblies was 17 per cent, and after the 2002 national elections, there were 74 women in the national assembly. A total of 14 of these came through general seats and the others on reserved seats. There were also 143 women members of provincial assemblies, of whom 15 came through direct elections and 128 via reserved seats.

After the 2001 LG election, the Women's Ministry (with assistance from UNDP) launched the 'Women's Political Participation Project' (W3P) to help the large number of newly elected women legislators in performing their jobs; and the 'Women's Political School' to train women councillors about their roles, powers and responsibilities in local government.

Although the Women's Ministry has played a proactive role in pushing women's effective presence in representative government at all levels, it has not always been favourable. The state has usually taken a patronising approach towards women, and most state institutions have dealt with women (as elsewhere in the world) in a welfare context. Women were seldom treated as individuals with political and economic entitlements. The official discourse on women's political rights, although present from the beginning in terms of lip service, has undergone extremely slow change. This is because attitudes within government, for multiple reasons, have been slow to recognise the urgency of mainstreaming women. The recommendations of various Commissions on the Status of women demonstrate this well.

Even though Zia-ul-Haq's government established a Commission on the Status of Women (1984) on the recommendations of the Women's Rights Committee (1976), the Commission's recommendations were ignored. This Commission recommended political parties to give 20 per cent of women members party tickets to contest elections. Another Commission on the Status of Women (1994-97) established by the PPP government to look into the repeal of the discriminatory Hudood Ordinances, recommended 33 per cent quotas at the local and national level through direct election and joint electorate. Again, this was ignored by the Nawaz Sharif government that took power in 1997.

However, by the time the Permanent Commission on the Status of Women was 
established by the Musharraf regime in 2000, substantive advocacy on reservation for women in politics resulted in a 33 per cent quota for women at the LG level.

Although women's presence in legislatures at the national, provincial and district levels has become more pronounced, reservations have elicited disdain and contempt among some government representatives. According to The Aurat Foundation Citizens' Report (n.d.: 3) one Minister for Local Government reportedly said:

Bibi, you don't know the situation on the ground. We are political people and we know the reality. If you reserve 33 per cent seats for women, you will find that very few genuine women will come forward willingly to contest these seats. In fact, you will find mostly servant girls and harlots will be brought forward by men to occupy the reserved seats.

Male politicians and government representatives commonly dismissed the idea of direct elections for women's reserved seats as being unrealistic in Pakistan's social conditions. They contended that 'there are no women out there'.

Although there has been a gradual overall increase in support to women from the government, this support was ambivalent during the 1990s when parliamentary democracy in Pakistan was precariously balanced between the two arch-rivals, the PPP and PML. However, during this decade, NGOs with different roles created spaces for women in the political arena by undertaking voter and candidate education/training programmes; lobbying parties for gender sensitive manifestos; and demanding that they practice affirmative action measures to enable women to enter the political arena, echoing the demands of the 1984 Report of the Commission on the Status of Women.

The exact arrangements for quotas - whether these should be on a party or non-party basis, through direct or indirect election, the percentage and constituencies to be covered were debated extensively throughout the 1990s. However, each elected government wanted to manipulate the arrangement such that the benefits would only accrue to the ruling party. Since each government had only a tiny edge over the opposition, none had enough support to ensure this, and quota arrangements remained unresolved. The last Sharif government defeated a private member's Bill for the restoration of lapsed parliamentary seats for women in May 1997, saying that the 20 reserved seats for women were to be part of a 'constitutional reform package' to be presented 'soon'. The package was never presented, nor were its contents shared with the public (Amnesty International 2008).

The deadlock at the national and provincial levels was not reflected at the LG level where the Sharif government managed to increase women's presence in three out of four provinces. While this government was not known for progressive views on women's rights, it favoured LG elections in continuity with the Zia regime, which had spawned the PML, the government's leading party. The Zia regime had generated a support base through political patronage and the PML government was able to extend this through Zia's protégés who were deeply entrenched at the LG level. Increasing the quota for women's representation at the LG level in 1993 at once demonstrated its supposedly pro-women stance, while also benefiting its political party interests.

The PPP-led government, meanwhile, constantly tried to undo the PML's support base at the LG level every time it came to power and in turn, was criticised for adopting an anti-LG stance and not doing enough for women beyond lip service. Women's political representation whether at the national or the local level was ultimately secondary to political party interests.

We need to analyse the intricate web of commonalities between military and civilian governments. Sometimes, the civilian regimes reflected continuity of policies with military regimes and sometimes they became symbols of ruptures and difference. The Sharif governments had more in common with the Zia regime than democratic regimes, e.g. he even tried to introduce Sharia in 1999. The Bhutto government, meanwhile, continued the economic policies of its military predecessor and was unable to institute reservations or party-based affirmative action for women despite its secular and pro-women credentials. Military regimes have also instituted quotas for women with more alacrity than civilian governments; however, some military governments have been more 
misogynistic than others - Zia-ul-Haq's Islamisation, for example, denied women their fundamental right to equality in legal matters and helped make rape and murder compoundable private crimes. The Sharif government gave women quotas in LG but nothing at the national and provincial levels; Sharif publicly sympathised with rape survivors and declared gang-rape punishable through capital punishment, yet he preserved the Hudood Laws that provided rapists and honour killers with refuge from the law. Eventually, Musharraf's military regime defanged the Hudood Ordinances with support from the PPP in the National Assembly. These criss-cross patterns are informed by political pragmatism on the one hand and by ideological continuities on the other.

4 Governmental policy on women, international commitments and donor influence

Various policy measures, international commitments and donor influences, as well as pressure brought by women's organisations and feminist activists have played a role in the formulation of national policies for women.

CEDAW (Convention for the Elimination of Discrimination Against Women) adopted by the UN General Assembly in 1979, was considered too politically sensitive to be discussed during the reign of General Zia-ul-Haq and was only ratified in 1995 at the time of the Beijing Conference on Women. During the 1990s, there was no clear policy on women, although there were some pro-women initiatives. The Women's Division was upgraded to the status of a Ministry, but it had a small budget and there were frequent changes in leadership - the secretary changed nine times between 1989 and 1993 preventing any consistent programme implementation or planning. The Ministry worked on producing a draft national policy on women, but it remained just a draft throughout the 1990s (Khan 1998: 23).

The National Policy for Empowerment and Development of Women, ${ }^{3}$ launched on 8 March (International Women's Day) 2000, reflected a changed government rhetoric. There was a shift from treating women as welfare recipients in the 1960 s, to attempts to enhance their social and economic status during the 1970 s and 1980 s, to the 2000 policy in which empowerment became a central goal. This empowerment included politics, and the resulting 33 per cent reservation at the LG level was a radical step that ushered in a fundamental change on the gendered political landscape.

The influence of the government's international commitments as well as international donors and multilateral institutions like the UN on policymaking in Pakistan is evident in this policy. For example, the prominent role of the Women's Political School funded by the UNDP and other decentralisation policy support emphasising 'good governance', 'new institutionalism' and 'participation of the poor' provided by the UK's Department for International Development (DFID), the Swiss Development Cooperation (SDC), and the German foundations, such as Friedrich Naumann Stiftung, indicate the influence of donor driven initiatives.

This can be interpreted in a positive as well as negative light. In the latter context, it would imply that the government enjoys little independence. Many donor-funded reports demonstrate an instrumentalist approach to women's rights, arguing that women's inclusion would yield improved development indices through effective service delivery. These reports also show scant understanding of the complex relationship between politics, culture, patriarchy and state institutions vis-á-vis women's rights. They relegate all ills to a retrogressive culture that together with corruption and poverty becomes the main barrier to women's empowerment. Women are portrayed as poor and vulnerable, whose rights need to be defended through external interventions. The mention of women's agency and voice is largely absent in donor literature, although their gains are mentioned and ascribed to patronage from male politicians. However, they seldom recognise the role of patriarchy in state institutions and consider misogynist social attitudes to be a result of culture alone. Donor influence is also analysed in a positive light, as many activists believe that the LG 33 per cent reservation largely resulted from the efforts of donors and women activists nationally and internationally who lobbied their respective governments to commit to women's political empowerment, through instruments such as CEDAW, the Beijing commitments and the recommendations of the Women's Commissions. 
5 The women's movement's role in Pakistan

The women's movement in Pakistan can be traced to its pre-independence origins when the vibrant nationalist movement in India mobilised many women as active participants in the struggle against British colonialism. Women's concerns in the initial years of Pakistan were focused on their immediate problem - the rehabilitation of thousands of displaced women through voluntary services. This was followed by the creation of the All Pakistan Women's Association (APWA), whose branches were established in every district by the District Commissioner's wife, who had to spearhead it in cooperation with the local elite who had supported the creation of Pakistan. Thus, the formal coming together of the state apparatuses and women's issues took place through APWA. APWA made its demands for women in a welfare mode throughout the 1950s and 1960s. It raised the issue of second marriage and demanded amendments in family laws, especially regarding the registration of marriage, divorce and polygamy as well as inheritance for orphans. The issue of political representation was also raised, although the constitution had guaranteed some representation through quotas.

By the end of the 1960s the UN 'Decade of Development' in Pakistan showed disastrous results: East Pakistan, with the majority of the population, had broken away due to unequal divisions of resources and political power. The process was brutal, as the military attempted to quell secession. Between 1.5 and 3 million people were killed and 200,000 women raped in 1970-1 (Khattak 1996). The Progressive Women's Organisation protested the rapes but by and large there was silence from organisations like APWA, whose members were wives of bureaucrats and the elite, who had a stake in the Pakistani state.

The 1970s marked the transformation of the women's movement. Issues of women's multiple roles, oppressions, and exploitation were being debated internationally, and women were questioning the structures that rendered them and their contributions invisible. In Pakistan, women's role was changing as the 1973 constitution had given them reserved seats at the provincial and national level for a period of 15 years and their visibility in the public arena was increasing under a liberal progressive political party. A new generation of women after attending western universities were returning home to teach or become journalists. These trends were arrested when the campaign to oust Zulfiqar Bhutto, couched in religious idiom, was launched in 1977. Bhutto's capitulation to the retrogressive forces and eventual hanging in 1978 heralded a critical change for women's rights.

General Zia-ul-Haq took over government through a military coup in July 1977 and began the process of 'Islamisation' of the country. Many of the gains that women had made over decades were reversed. For instance, the founder of Pakistan, Mr M. Ali Jinnah had stated in a speech in 1944 that, 'It is a crime against humanity that our women are shut up within the four walls of the house like prisoners' (Lewis 2001), but this was exactly what Zia-ul-Haq attempted to do through his campaign of 'chador aur chaar deevari' (veil and the four walls) for women in the 1980s by making it state policy for women to cover their heads on television, observe purdah while attending college, not to participate in sports, etc. The Women's Action Forum (WAF) was formed in 1981 to protest against state policies that sanctioned discrimination through the legal system and anti-women interpretations of Islam. Made up largely of upper and middle class educated urban women in Karachi, Lahore and Islamabad, WAF has worked as a lobbying group along the principles of collective leadership and non-hierarchy.

By the late 1980s, some important developments had taken place: the Islamisation process had taken root, extensively funded by the state for reasons of legitimacy and pragmatism and with support from foreign countries for the Afghan Jihad. At the same time, opposition had grown to the regime's anti-women and anti-minorities laws and human rights violations, such as the introduction of medieval forms of punishment as well as media censorship. This coalesced in three forms: the creation of WAF; the creation of advocacy and development NGOs; and the coalition between NGO workers, intellectuals and progressive political parties against military rule. These developments culminated in the Movement for the Restoration of Democracy. The women's movement took the lead in demanding not only legal and political reform of the system in favour of women but also challenged and exposed the militarisation of the state and society. 
Throughout the 1990s, women activists demanded increased political representation and worked with the government (especially the PPP government whose leaders it had joined in the Movement for the Restoration of Democracy) to outline priorities for women. They debated their position and status in mainstream politics to determine whether they should exert influence from outside or directly through joining mainstream political parties. For the most part, they pushed the state and political parties to create space for them through affirmative action for women's representation at all levels of government and by ensuring a quota for women within political party structures. These demands came from the platform of WAF as well as the NGOs that promoted rights-based approaches to development. These groups were able to bring a change in the political discourse about women and even conservative political parties were forced to raise and include women's political representation in their manifestos. The campaign against discriminatory laws had been continuous and sustained for almost 25 years, when they were eventually changed through the Women's Protection Bill in 2006.

Women activists also supported the government, especially the Benazir Bhutto governments, in outlining policy priorities for women. In this connection, women activists facilitated Pakistan's international commitments and representation at conferences and forums. In contrast to others, activists did not produce an alternative to the official report for the Beijing conference (1995), as the official one was jointly owned by NGOs, the women's movement and the government. The post-Beijing National Platform for Action and its implementation through the National Plan of Action were massive projects that were executed by the government in collaboration with representatives of the women's movement, who were also working with NGOs (Weiss 2001). Thus, there was overall cooperation between the government and the women's movement at the same time as points of difference and tension between the two.

\section{NGOs and women's rights}

The emergence of the NGO sector in 1980s' Pakistan, in reaction to authoritarian rule and unjust policies, is critiqued as a donor-funded phenomenon. As many NGOs challenge the status quo, they are accused of promoting foreign agendas and the legitimacy of their work is often questioned by conservative sections of state and society on the basis of the foreign funding they receive. This is especially the case with women's rights and equality issues, which question cultural biases and anti-women interpretations of religiously sanctioned laws.

Although a large number of NGOs are involved with women's rights work, ${ }^{4}$ as the prominent ones are staffed by middle and upper middle class women and men, they are seen to be disconnected from the grassroots. Some of the influential NGOs like Shirkat Gah, Aurat Foundation, ASR (Applied Social Research) Institute, Simorgh, Rozan and AGHS (Asma Jahangir, Gulrukh Rehman, Hina Jilani and Shahla Zia) were established by leading activists of the women's movement who are involved in research and advocacy. They carved a space for themselves by actively contributing to dialogues with the government and serving on government committees and Commissions that address women's issues. The activists in these NGOs have therefore changed the shape of the policymaking process in Pakistan by lobbying continuously for women's political, legal and economic rights: they demanded 33 per cent political representation for women at all levels of government; they insisted on the repeal of discriminatory Hudood Laws; they demanded an end to violence against women, and a recognition of the economic contribution of women in the government's labour indices. ${ }^{5}$

As many women activists were involved in NGO work, the role of NGOs and the women's movement became diluted as the two merged into each other at different times and the women's movement became NGO-ised (Bari and Khattak 2001). Given the cooperation between the PPP government and NGOs in general, there was trust at several levels; thus, the delegation to Beijing included several leading NGO and women's rights activists. Several members of the Commission on the Status of Women set up to examine discriminatory laws in 1996 were women's rights activists. Different donor funded projects for the government were initiated upon the urging of leading women's organisations. For example, violence against women came to the centre of media attention with the Zainab Noor case in 1993 in which Zainab was severely tortured, with damage to three vital organs, by her prayer leader husband. While Zainab Noor 
was sent abroad at state expense for treatment, the government set up burn centres and there was renewed interest in improving crisis centres.

Voices from the women's movement, spearheaded by WAF, permeated the discourse of the government, the donors and the NGOs as many women activists 'wore several hats'. They were running their own organisations; they sometimes took assignments with donors or became consultants; at other times they served in gratis capacity on government commissions and authored government reports. One example is Shahla Zia, widely respected for her stand on women's rights, who authored the excellent baseline report on women in local government, was one of the authors of the Women's Commission Report of 1997, wrote several Aurat Foundation reports, headed the Legislative Watch Group of Aurat Foundation and authored reports for UNDP. Shahla was not an exception. ${ }^{6}$ What should be noted is that the voices of women, while they were channelled through different institutional prerogatives, were present everywhere and helped make an impact far greater than their numbers.

It was the consistent focus of the women's movement and like-minded NGOs that kept the issues of discriminatory legislation and women's political representation in the public eye. Thus, the announcement by Musharraf's military regime in 2000 that women would be granted 33 per cent seats in LG came as a relief rather than a surprise. Finally, after more than a decade of struggle for political representation, women had gained the space to exercise their political rights. There were opportunities for women to prove themselves and bring meaningful change into the system. The credit for bringing women into the mainstream of politics thus goes to women's rights and human rights activists as well as to the military regime that was able to bypass political party interests and institute affirmative action for women.

\section{Conclusion}

This article outlines the position of the major stakeholders regarding women's reserved seats: military and civilian governments, donor agencies, the women's movement and women's rights NGOs. It is clear that different governments hold widely varying positions and even institutions within one government can hold and promote diametrical views. It is important to understand these nuances. The policies for promoting women's rights have been quite wide ranging - as seen in the contrast between Zia-ul-Haq who wanted women to stay behind the four walls while granting them quotas and the Benazir Bhutto governments that included women in decisionmaking but failed to provide them with quotas.

The analysis of NGOs' roles indicates that they have mobilised women as voters and candidates as well as provided capacity building training and helped organise women councillors to form networks. The strong voice of women's rights activists and the women's movement is clear and permeates through all three distinct and different discourses from donors, the government and NGOs on women's political representation experience in Pakistan. This reflects the shaping of voice by institutions. While the women speak, institutional frameworks are applied so that they sound distinctly different even though the author may be the same. Government reports reflect the concerns of women nationally and internationally but at the same time various in-built clauses such as holding everything subordinate to a constantly shifting definition of Sharia/Islam make these reports palatable to the government; donor reports are very careful about criticising the government but they are ever-ready to blame culture and tradition. NGO reports traverse the uneasy path between donor conditions for acceptability and policy impact and strong feminist analyses.

I conclude that women's struggles at the grassroots can be successful and provide visible results when women enjoy state as well as societal support. Given that neither are straightforward to obtain, the pathways to women's political empowerment are necessarily uneven and unpredictable. Women have to negotiate for spaces within patriarchal norms that often do not allow them to make substantive gains or to capitalise on them once the gains have been allowed. Women's struggles are thus complex and take place in multiple contexts and settings. They may succeed in one area and be pushed back in another. However, the important point that emerges is women's persistent struggle against odds through support from the same structures that can impede them. How these struggles and contradictions within masculinist structures are negotiated, decides the terms and relative success of women councillors at the individual level. 
Notes

* This is a shortened version of a paper by the same author, published in Azim and Sultan (2010).

1 President Musharraf resigned on 18 August 2008 and an acting president was appointed, later replaced by President Asif Zardari. However, no new policy has been announced by the coalition government, therefore the policy analysis here is restricted to the initiatives of the Musharraf regime in connection with LG as well as women.

2 According to the NRB (National Reconstruction Bureau), the present system of decentralisation is based on a model of 5Ds: devolution of political power, distribution of resources to the districts, diffusion of the power authority nexus, decentralisation of management functions and decentralisation of administrative authority (Yazdani 2003).

3 This policy was available on the website of the Ministry for Women's Development until May 2008 but has been removed since after a change in government. No new policy has replaced it at the time of writing.

4 There are no reliable figures available about the number of NGOs focusing on women's issues. A 2002 study by the SPDC (Social Policy and Development Centre) places the total

\section{References}

Amnesty International (2008) Pakistan: No Progress on Women's Rights, www.amnesty.org/en/library/ asset/ASA33/013/1998/en/dom-SA330131998 en.html (accessed 21 August 2008)

Aurat Foundation (n.d.) Citizens' Report, Islamabad: The Aurat Foundation

Azim, F. and Sultan, M. (eds) (2010) Mapping

Women's Empowerment: Experiences from Bangladesh, India and Pakistan, Dhaka: University Press Limited

Bari, F. and Khattak, S.G. (2001) 'Power Configurations in the Private and Public Arenas: The Women's Movement's Response', in A.M. Weiss and S. Zulfiqar Gilani (eds), Power and Civil Society in Pakistan, Oxford: Oxford University Press

Government of Pakistan (1973) Constitution of the Islamic Republic of Pakistan, Islamabad: Government of Pakistan

Khan, A. (1998) Women and the Pakistan Government: A Brief Policy History (1975-1998), Islamabad: United Nations Development Fund number of non-profits at 45,000 in Pakistan, with a majority focusing on education and research (46.4 per cent), including religious education and 17.5 per cent looking at civil rights and advocacy issues.

5 For a good overview of the development of the NGO sector and its relations with the state in Pakistan, see Khan (2001).

6 Other examples are Farida Shaheed and Khawar Mumtaz, authors of several government reports and responsible for Beijing Plus Five and Beijing Plus Ten through Shirkat Gah; Ayesha Khan, independent consultant, WAF member who authored the report on the Pakistan government policies on women for the UNDP; Farzana Bari, author of several donor reports on women and political representation as well as the acting director of the Center for Women's Studies; Nafisa Shah who has been a women's rights activist, journalist, Nazim (chief elected local government official) and has consulted for UNDP; and Tahira Abdullah, an ardent women's rights activist, who has worked with UNFPA and been a founding member of WAF. The voices of these women and several others like them have permeated different reports in different forums organised by NGOs, the government and donors.

Khan, O.A. (2001) 'Critical Engagements: NGOs and the State', in A.M. Weiss and S. Zulfiqar Gilani (eds), Power and Civil Society in Pakistan, Oxford: Oxford University Press

Khattak, S.G. (1996) Women and Local Government, SDPI Working Paper Series No 24, Islamabad: Sustainable Development Policy Institute

Lewis, J.J. (2001) Pakistan: Status of Women and the Women's Movement, http://womenshistory.about.com/library/ency/ blwh_pakistan_women.htm (accessed 31 August 2008)

National Reconstruction Bureau (2006) 'Monitoring the Implementation of Status of Reforms', presentation from one day seminar on 23 December 2006, www.nrb.gov.pk/isr/ (accessed 2 July 2010)

Social Policy and Development Centre (2002) Dimensions of the Non-Profit Sector in Pakistan, www.pcp.org.pk/pdf/John\%20Hopkins\%20-\%20 Nature\%20and\%20dimensions\%20of\%20the\% 20nonprofit\%20sector\%20in\%20Pakistan.pdf (accessed 1 March 2009) 
Weiss, A.M. (2001) 'Gendered Power Relations: Perpetuation and Renegotiation', in A.M. Weiss and S. Zulfiqar Gilani (eds), Power and Civil Society in Pakistan, Oxford: Oxford University Press
Yazdani, F. (2003) Women's Representation in Local Government in Pakistan: Impact Analysis \& Future Policy Implications, Islamabad: International Policy Fellowships 